Tropical Journal of Pharmaceutical Research March 2019; 18 (3): 555-561

ISSN: $1596-5996$ (print); 1596-9827 (electronic)

(C) Pharmacotherapy Group, Faculty of Pharmacy, University of Benin, Benin City, 300001 Nigeria.

Available online at http://www.tjpr.org

Original Research Article

http://dx.doi.org/10.4314/tjpr.v18i3.16

\title{
Pharmacological effects of active saponins from Panax ginseng Meyer
}

\author{
Sin Ja Bae ${ }^{1}$, Gyu Jin Rho ${ }^{2}$, Kang Min Kim ${ }^{3 *}$, Jae Seon Kang ${ }^{1 *}$ \\ ${ }^{1}$ Department of Pharmacy, Kyungsung University, Busan, ${ }^{2}$ OBS/Theriogenology and Biotechnology, College of Veterinary \\ Medicine, Gyeongsang National University, Jinju, ${ }^{3}$ Department of Pharmaceutical Science and Technology, Kyungsung \\ University, Busan, Republic of Korea
}

${ }^{*}$ For correspondence: Email: kimkmks@ks.ac.kr; Tel: +82-51-663-4891

Sent for review: 20 November 2018

Revised accepted: 21 February 2019

\begin{abstract}
Purpose: To investigate the pharmacological effects of the active saponins isolated from Panax ginseng Meyer (P. ginseng) via extraction, heat treatment, and enzyme conversion.

Methods: The effects of active saponins on rat blood were determined using a multichannel analyzer. The population doubling time (PDT) of mesenchymal stem cells (MSCs) and human-derived leukocyte cancer cells (A549) was determined by cell counting. b-galactosidase was measured in human toothderived stem cells (HTS) using a $\beta$-galactosidase ELISA kit.

Results: Intraperitoneal administration of active saponins resulted in $30.09 \%$ increase in red blood cell count and $55.55 \%$ decrease in blood triglyceride concentrations. The stimulatory effect of active saponins $(10 \mathrm{ng} / \mathrm{mL})$ on cellular differentiation was determined based on PDT of MSCs, which decreased by $33.82 \%$ compared to control. A $22.29 \%$ increase in PDT of A549 cells demonstrated the suppressive effects of active saponins on cancer cell growth. Active saponins (10 $\mathrm{ng} / \mathrm{mL})$ also decreased intracellular $\beta$-galactosidase concentration by $20.42 \%$ in HTS cells.

Conclusion: Administration of active saponins to rats extends the lifespan, promotes differentiation in MSCs, suppresses A549 cell differentiation, and reduces TG and b-galactosidase associated with aging in HTS. Thus, active saponins have potentially beneficial effects in humans.
\end{abstract}

Keywords: Active saponin, $\beta$-Galactosidase, Doubling time, Mesenchymal stem cells, Panax ginseng

This is an Open Access article that uses a funding model which does not charge readers or their institutions for access and distributed under the terms of the Creative Commons Attribution License (http://creativecommons.org/licenses/by/4.0) and the Budapest Open Access Initiative (http://www.budapestopenaccessinitiative.org/read), which permit unrestricted use, distribution, and reproduction in any medium, provided the original work is properly credited.

Tropical Journal of Pharmaceutical Research is indexed by Science Citation Index (SciSearch), Scopus, International Pharmaceutical Abstract, Chemical Abstracts, Embase, Index Copernicus, EBSCO, African Index Medicus, JournalSeek, Journal Citation Reports/Science Edition, Directory of Open Access Journals (DOAJ), African Journal Online, Bioline International, Open-J-Gate and Pharmacy Abstracts

\section{INTRODUCTION}

Korean ginseng $P$. ginseng has long been regarded as the best traditional herbal medicine in East Asia [1]. Different types of ginseng such as wild ginseng, wood-cultivated ginseng, cultivated roots ginseng, water culture ginseng, $P$. quinquefolius L., $P$. notoginseng, and red ginseng have varying compositions and contents of saponin and non-saponin substances [2,3]. Saponin and non-saponin substances (panacen, polysaccharides, amino acid derivatives, polyacetylene derivatives, and phenol compounds) present in $P$. ginseng exert a wide range of pharmacological activities such as elimination of harmful free radicals and anticancer, antihypertensive, hypolipidemic, and hepatoprotective effects [4]. 
Saponins, the main pharmacological components of ginseng, can be classified as protopanaxadiol (PPD)-based saponins and protopanaxatriol (PPT)-based saponins. PPD-based saponins have a chemical structure in which various substituents are bonded to the basic structure of PPD. Ginsenosides Rb1, Rb2, Rc, Rd, F2, Rg3, and compound $\mathrm{K}$ are representative PPD-based saponins. Similarly, PPT-based saponins have PPT as a basic structure and its major representative ginsenosides are $\mathrm{Re}, \mathrm{Rf}, \mathrm{Rg} 1$, and Rh1 [5]. The major pharmacological properties of ginsenosides are modulation of various ion channels and cellular signal transduction pathways, amelioration of vascular dysfunction, normalization of lipid profiles, prevention of myocardial ischemia through improved blood circulation, cardiac function, and blood pressure, and anti-oxidant effects [6]. Previous studies have shown that compound $\mathrm{K}$ exerts anti-inflammatory, hepatoprotective, neuroprotective, anticancer, anti-oxidant, and anti-diabetic effects. [7-11].

The objective of the present study was to investigate the effects of active saponins from wood-cultivated ginseng on rat blood. In addition, this study investigated the effects of saponins on differentiation and lifespan of MSCs and A549. Finally, this study investigated $\beta$-galactosidase levels in HTS.

\section{EXPERIMENTAL}

\section{Reagents and animals}

Ginsenoside standards (Rb1, Rb2, Rc, Rd, F2, and compound $\mathrm{K}$ ) were purchased from Ambo Institute (Daejeon, Korea). Ginsenoside standards (Rg1 and $\mathrm{Rg} 3$ ) were provided by the Ministry of Food and Drug Safety (MFDS). HPLC solvents were purchased from J. T. Baker Chemical Co. (Phillipsburg, NJ, USA). Pectinase TF (Rapidase TF $^{\circledR}$ ) was purchased from DSM Food Specialties (Delft, The Netherlands). All other chemicals and solvents were obtained from Sigma (St. Louis, MO, USA) and media were obtained from Gibco (Invitrogen, Burlington, ON, Canada), unless otherwise specified. Male Sprague Dawley (SD) rats were purchased from Hyochang science (Daegu, Korea).

The rats were housed and allowed to acclimate for one week to the following conditions: $23 \pm 1$ ${ }^{\circ} \mathrm{C}$ (controlled temperature), $60 \pm 5 \%$ (relative humidity) and a $12 \mathrm{~h}$ light/12 $\mathrm{h}$ dark cycle. The study was performed in accordance with World Health Organization guidelines and was approved by the Institutional Review Board of Kyungsung University for evaluation of safety and efficacy of herbal medicines (confirmation no. Research-2014-14A).

\section{Preparation and analysis of active saponins}

$P$. ginseng was purchased from the Simmani Wild Ginseng Farming Association (Hamyang, Kyungnam, Korea) in 2014. A voucher specimen of $P$. ginseng was deposited at the herbarium located at the College of Pharmacy, Kyung Sung University (no. 14-01-WG).

P. ginseng was heat treated three times at $121^{\circ} \mathrm{C}$ using an autoclave offset to a pressure of 1.1 $\mathrm{kg} / \mathrm{cm}^{2}$ for $10 \mathrm{~min}$. Heat-treated ginseng was cooled to $90{ }^{\circ} \mathrm{C}$ between each autoclave cycle. Prepared active ginseng $(1.5 \mathrm{~kg})$ was ground for fine powder and active saponins were extracted with $80 \%$ ethanol $(7,500 \mathrm{~mL})$. The extracted saponins were filtered using a $500 \mu \mathrm{m}$ particle filter to remove particulate matter. The filtered ethanolic solution was evaporated using a rotary evaporator. The dried active saponins were dissolved in sterilized distilled water $(0.23 \%$ $\mathrm{w} / \mathrm{v})$. Rapidase TF $(600 \mathrm{~mL})$ and $50 \mathrm{mM}$ sodium acetate buffer $(3,150 \mathrm{~mL}, \mathrm{pH} 4.5)$ were added at a flow rate of $5 \mathrm{~mL} / \mathrm{min}$ to $25 \mathrm{~L}$ of $0.23 \%$ active saponins using a peristaltic pump.

The solution was then incubated with constant agitation (150 rpm) at $50{ }^{\circ} \mathrm{C}$ for $10 \mathrm{~h} \mathrm{[12].} \mathrm{The}$ prepared samples were collected by centrifugation, resuspended in ethanol, and filtered to obtain a concentrate. Identification of active saponins from wood-cultivated ginseng was performed using an Agilent 1200 series HPLC system (Agilent Technology, Santa Clara, CA, USA) equipped with a Zorbax SB-C18 column $(150.0 \times 4.6 \mathrm{~mm}, 5 \mu \mathrm{m})$ and a Corona CAD (Thermo Scientific) detector set to $230 \mathrm{~nm}$ with a flow rate of $1 \mathrm{~mL} / \mathrm{min}$ [5].

\section{Animal studies}

Rats were divided into a control group, and an experimental group (treated with active saponins) $(n=5)$. Rats in the control group received $1 \mathrm{~mL}$ saline solution intraperitoneally at 10:00 anti meridiem (a.m.) daily for 37 days. Rats in the experimental received $1 \mathrm{~mL}$ of intraperitoneal active saponins solution $(1.25 \mathrm{mg} / \mathrm{kg}$ body weight) containing $0.01 \%$ polysorbate 80 at 10:00 a.m. daily for 37 days. At day 38 , blood samples were collected and hemoglobin $(\mathrm{Hb})$, hematocrit (HCT), red blood cells (RBCs), platelets, high-density lipoprotein (HDL), total cholesterol (T-CHO), and low density lipoprotein (LDL) were measured to evaluate anti-aging effects. Blood analysis data were obtained from 
Green Cross Labs Co. Ltd., a specialized blood analysis agency.

\section{Isolation and culture of mesenchymal stem cells (MSCs)}

MSCs were isolated from two different human adult tissue sources: umbilical cord and dental tissue, according to previously described protocols $[13,14]$. Informed consent was obtained from the patients. Tissue samples were harvested and aseptically transported from the Gyeongsang National University Hospital in accordance with the Gyeongsang National University Ethical review committee guidelines for clinical research (GNUH IRB-2012-091-004). Briefly, umbilical cords (UC) were chopped into small explant pieces, and placed onto pre-coated $35 \mathrm{~mm}$ culture plates, then incubated in an inverted position inside a humidified incubator maintained at $5 \% \mathrm{CO}_{2}$ and $37^{\circ} \mathrm{C}$. After $2 \mathrm{~h}, 1 \mathrm{~mL}$ of advanced Dulbecco's Modified Eagle's Medium (ADMEM) supplemented with $10 \%$ Fetal Bovine Serum (FBS) was carefully poured to prevent detaching the tissue explants. Cellular outgrowth from the explants was observed over 8-10 days. Explants were then carefully removed using sterile forceps.

Cells at $70-80 \%$ confluence were trypsinized with $0.25 \% \quad(\mathrm{w} / \mathrm{v})$ trypsin-EDTA and further subcultured. Human dental tissues were minced thoroughly and enzymatically dissociated using $0.1 \%$ collagenase- 1 solution. The digested tissue was serially filtered through $100-\mu \mathrm{m}$ and 40- $\mu \mathrm{m}$ cell strainers (Corning, USA) and the aspirate was centrifuged at $300 \mathrm{~g}$ for $5 \mathrm{~min}$. After washing the pellet twice with Dulbecco's phosphate buffered saline (DPBS), cells were suspended in 10\% ADMEM and seeded onto 35$\mathrm{mm}$ culture dishes. The media were changed twice per week. A549 cells (a human immortalized lung cancer cell line) was purchased and maintained in 10\% ADMEM. The media were changed twice per week. Growth behavior of cells was monitored using an inverted phase contrast microscope (Nikon DIAPHOT 300, Japan).

\section{Assessment of population doubling time (PDT)}

Cells at the third passage were trypsinized and centrifuged. Cell pellets were resuspended in 5 $\mathrm{mL}$ of culture medium. Cell counting was performed using a hemocytometer. Cell suspensions were diluted to and plated on 6-well plates (surface area $9 \mathrm{~cm}^{2}$ ) at a cell density of 1 $x 10^{5}$ cells/well. Cells in culture plates were mixed well to ensure a uniform distribution, then transferred to a humidified incubator. Cell counting was performed after $72 \mathrm{~h}$ for all experimental groups. The PDT of cells treated with active saponins $(1,5,10,20$, and $50 \mathrm{ng} / \mathrm{mL})$ was calculated using Eq 1.

$\mathrm{PDT}=\mathrm{T}(\log 2) /(\log N h-\log N t)$

where $\mathrm{T}$ is the culture time whereas $\mathrm{N} h$ and $\mathrm{N} t$ represent the initial and final cell number before and after seeding, respectively. All experiments were performed in triplicate.

\section{Determination of mammalian $\beta$-galactosidase activity}

HTS from three volunteers (Den1, Den2, and Den3 cells) were evaluated for the occurrence of senescence using $\beta$-galactosidase kit (Thermoscientific, Rockford, USA). All the $\beta$ galactosidase assay reagents were slowly thawed and equilibrated at room temperature (without heating). Following the third passage, when MSCs were at $70-80 \%$ confluence, the cells were trypsinized and thoroughly washed with DPBS. After centrifuging the cells at $2500 \times$ $g$ for $10 \mathrm{~min}$, the supernatant was discarded, and the cells were washed one more time. After discarding the supernatant, $M-P E R^{\circledR}$ reagent (Mammalian protein extraction reagent) was added to the cell pellet to extract total cellular protein.

The cells were agitated gently for $10 \mathrm{~min}$ at room temperature. The cell suspension reagent mixture was centrifuged at $27000 \times g$ for 15 min and cell debris was removed from the lysate, resulting in a clear cell supernatant extract. Fifty microliters of clarified cell extract and $20 \mu \mathrm{L}$ of active saponins $(10 \mathrm{ng} / \mathrm{mL})$ were transferred to a microwell plate, followed by addition of $50 \mu \mathrm{L}$ of $\beta$-galactosidase assay reagent. The plate was covered and incubated for $30 \mathrm{~min}$ at $37^{\circ} \mathrm{C}$. The reaction was stopped by adding $100-150 \mu \mathrm{L}$ of $\beta$-galactosidase stop solution. Absorbance was measured at $405 \mathrm{~nm}$ using an ELISA reader (Bio-Tek, USA). All experiments were performed using $10 \mathrm{ng} / \mathrm{mL}$ treatments with active saponins in triplicate to calculate the standard deviations.

\section{Statistical analysis}

Data are expressed as mean \pm SD values. Statistical analyses were performed using the SigmaPlot 10.0 program (Systat Software Inc., Chicago, USA). Values were compared to control using analysis of variance (ANOVA) followed by Bonferroni post hoc tests. $P<0.05$ was considered statistically significant. 


\section{RESULTS}

\section{Active saponins}

About $30 \mathrm{~g}$ of concentrate was prepared from 1.5 $\mathrm{kg}$ of wood-cultivated ginseng. HPLC analysis of the active saponins showed that the content of compound $\mathrm{K}$ was $52.03 \pm 2.58 \%$, Rd was 34.40 $\pm 1.87 \%$, F2 was $2.69 \pm 1.39 \%$, and $\mathrm{Rg} 3$ was $2.01 \pm 0.58 \%$, with respect to the total saponin content.

\section{Biochemical parameters}

Table 1 shows results of analysis of rat blood samples. Triglyceride (TG) levels were significantly reduced (by $55.55 \%$ ) in the experimental group $(250.33 \pm 10.07 \mathrm{mg} / \mathrm{dL})$ compared to those in the control group (450.66 \pm $9.50 \mathrm{mg} / \mathrm{dL}$ ). Total HCT increased from $45.04 \pm$ $2.76 \%$ to $57.86 \pm 3.98 \%$. A $30.09 \%$ increase in RBC was observed, from $7.01 \pm 3.12 \times 10^{6} / \mu \mathrm{L}$ in the control group to $9.12 \pm 2.67 \times 10^{6} / \mu \mathrm{L}$ in the experimental group (Table 1 ).

Table 1: Serum biochemical parameters of rats administered active saponins intraperitoneally for 37 days

\begin{tabular}{lcc}
\hline Parameters & $\begin{array}{c}\text { Control } \\
\text { group }\end{array}$ & $\begin{array}{c}\text { Experimental } \\
\text { group }\end{array}$ \\
\hline $\mathrm{RBC}\left(10^{6} / \mu \mathrm{L}\right)$ & $7.01 \pm 3.12$ & $9.12 \pm 2.67^{*}$ \\
$\mathrm{WBC}\left(10^{3} / \mu \mathrm{L}\right)$ & $7.54 \pm 2.17$ & $6.65 \pm 1.19$ \\
$\mathrm{HCT}(\%)$ & $45.04 \pm 2.76$ & $57.86 \pm 3.98$ \\
$\mathrm{Hb}(\mathrm{g} / \mathrm{dL})$ & $15.76 \pm 1.54$ & $16.90 \pm 1.11$ \\
$\mathrm{Platelet}$ & $1,027 \pm 154.63$ & $1,160 \pm 129.40$ \\
$\left(10^{3} / \mu \mathrm{L}\right)$ & $450.66 \pm 9.50$ & $250.33 \pm 10.07$ \\
\hline $\mathrm{TG}(\mathrm{mg} / \mathrm{dL})$ &
\end{tabular}

All values are represented as mean \pm SD $(n=5)$; "significantly different from the control group $(p<0.05)$

\section{MSCs and A549 differentiation potential}

In the MSC control group, the doubling time was $46.01 \pm 2.14 \mathrm{~h}$. Active saponin treatment (10 $\mathrm{ng} / \mathrm{mL}$ ) reduced doubling time of MSCs to 30.45 $\pm 0.52 \mathrm{~h}$ (Figure 1). Doubling times for MSCs treated with $1,5,20$, and $50 \mathrm{ng} / \mathrm{mL}$ of active saponins were $44.85 \pm 1.24,36.23 \pm 0.88,38.97$ \pm 0.97 , and $42.97 \pm 0.98 \mathrm{~h}$, respectively (Figure 1). For $A 549$ cells, the average doubling time of the control group was $20.12 \pm 0.25 \mathrm{~h}$. Treatment with $10 \mathrm{ng} / \mathrm{mL}$ of active saponins increased doubling time to $25.56 \pm 1.52 \mathrm{~h}$ (Figure 1). Although the average doubling time of A549 cells increased following treatment with all concentrations of active saponins, the highest doubling time was observed in response to treatment with $10 \mathrm{ng} / \mathrm{mL}$ of active saponins. Treatment with $1,5,20$, and $50 \mathrm{ng} / \mathrm{mL}$ of active saponins resulted in doubling times of $21.44 \pm$ $1.44,22.43 \pm 1.88,22.57 \pm 0.87$, and $23.97 \pm$ $1.24 \mathrm{~h}$, respectively (Figure 1 ).

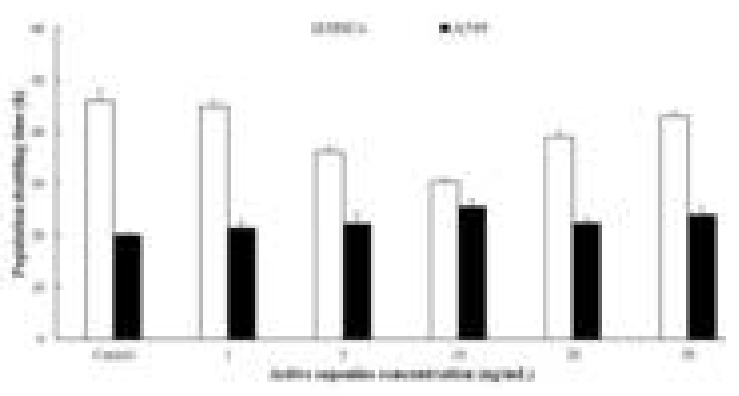

Figure 1: Doubling time of mesenchymal stem cells (MSCs) and human-derived leukocyte cancer cells (A549) following treatment with active saponins. The population doubling time was calculated based on cell counts. Results are expressed as means $\pm S D(n=5)$. ${ }^{*} p<0.05$ when compared to control

\section{Activity of $\beta$-galactosidase in human tooth- derived stem cells}

$\beta$-galactosidase levels in HTS were measured by ELISA [15]. $\beta$-galactosidase activity in active saponin treated-HTS cells was significantly $(p<$ 0.05 ) lower than that in the control cells (only HTS cells) (Figure 2). In the first subject, Den1, $\beta$-galactosidase content was reduced by $27.03 \pm$ $0.57 \%$ compared with that of the control group. In the second subject, Den2, $\beta$-galactosidase content was reduced by $22.09 \pm 0.74 \%$ compared with that of the control group. In the third subject, Den3, $\beta$-galactosidase content was reduced by $12.14 \pm 0.17 \%$ compared with that of the control group. An average reduction of 20.42 $\pm 0.49 \%$ was observed, which was associated with the lifespan extension of the cells. $\beta$ galactosidase activity was observed in HTS cells treated with or without $10 \mathrm{ng} / \mathrm{mL}$ active saponins as shown in Figure 3.

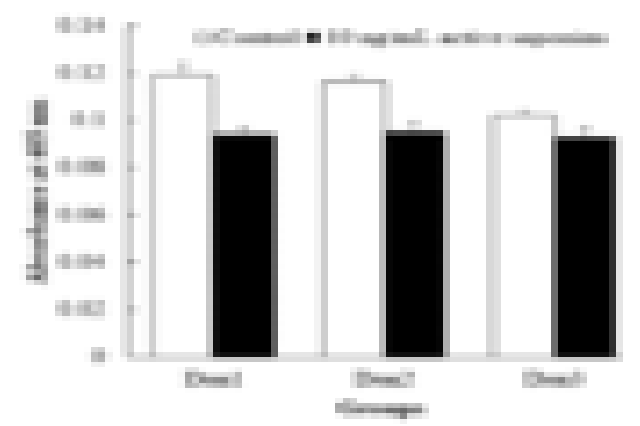

Figure 2: Inhibition of $\beta$-galactosidase in human toothderived stem cells treated with active saponins (10 $\mathrm{ng} / \mathrm{mL}) ;{ }^{*} p<0.05$ compared to control 


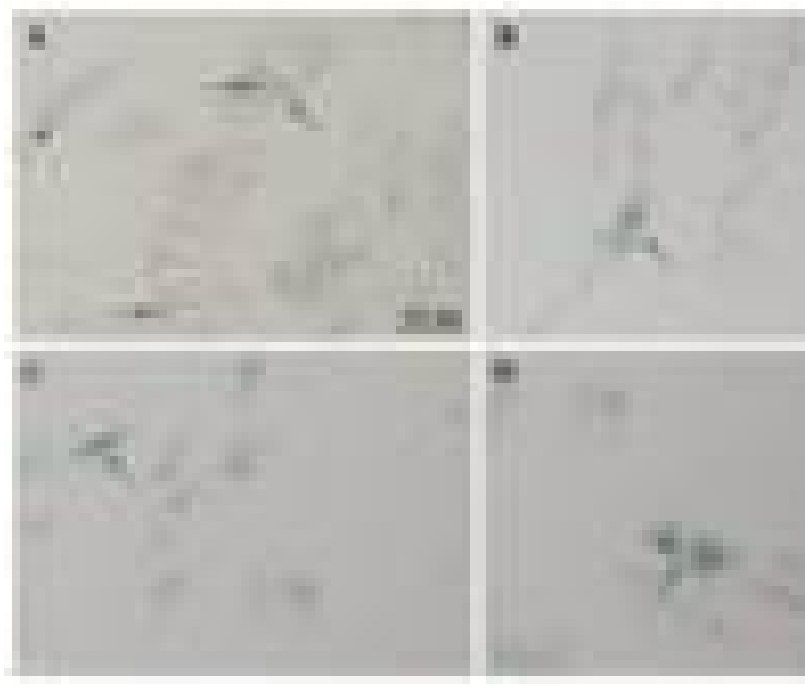

Figure 3: $\beta$-galactosidase staining of human toothderived stem cells treated with active saponins (10 ng/mL). (A) Control, (B) Den1, (C) Den2, and (D) Den3 groups. Positive senescence-associated $\beta$ galactosidase staining is represented by blue granules (arrow), which were seen in a greater number of control cells than in Den1, Den2, and Den3

\section{DISCUSSION}

This study describes extraction, preparation, and use of active ginseng saponins obtained from wood-cultivated ginseng roots. At least $90 \%$ of saponin contents comprised compounds $\mathrm{K}$, Rd, F2, and Rg3. The findings from these studies show effects of active saponins on cellular lifespan (including $\beta$-galactosidase) cell differentiation, RBC count, and TG levels.

Ginseng products are typically composed of high water-solubility saponins. However, inactive ginseng saponins with high water solubility are not easily absorbed in the intestines, resulting in limited pharmacological effects. However, when saponins are activated (active saponins), they are less water-soluble, but are more easily absorbed, in the intestines resulting in improved pharmacological effects [16]. Many glycoside compounds show increased physiological activity when the sugar are degraded to aglycone [17]. The saponins Rg3, Rh1, Rh2, F2, CY, and CK, produced by hydrolysis of sugars, are more readily absorbed and exert greater physiological activity than the saponins Rb1, Rb2, Rd, and Re, which are bound to three or more sugars [18]. Manufacturing active saponins (compound $\mathrm{K}$ ) can be very difficult. In this study, extracts with high active saponin content (compound K: $52.03 \%$, $\mathrm{Rd}: 34.40 \%$, $\mathrm{F} 2: 2.69 \%$, and $\mathrm{Rg} 3$ : $2.01 \%$ ) were prepared by heat decomposition $\left(121{ }^{\circ} \mathrm{C}\right)$ and enzymatic reaction (Rapidase). Several studies have reported that compound $\mathrm{K}$ is to be converted a content of $>80 \%$ from ginseng extract, crude saponins, or pure saponins such as substrate using organic solvents (butanol, methanol, chloroform, ethyl acetate, and dichloromethane) [19,20]. The content of compound $\mathrm{K}$ including other active saponins is higher than this result. However, the compound $\mathrm{K}$ of this result do not use many organic solvents (only ethanol). It is many advantages for pharmaceutical uses.

This study attempted to identify internal factors (biochemical parameters) among various causes of aging using blood analysis. As individual's age, deterioration of liver function, deterioration of kidney function, memory loss, and excessive increases in total fat and triglyceride levels contribute to onset and progression of many diseases. Aging can also be defined as a process in which susceptibility to disease and death increases, and the body becomes debilitated [21]. Study of aging in rodent models is a time-consuming process due to difficulty in breeding and designing appropriate experiments to study biochemical deterioration [22].

Therefore, studies are typically performed through blood analysis. Active saponins containing prepared compound $\mathrm{K}$ were administered to aging SD rats, and blood analysis was performed. Blood analysis in the experimental group showed a $55.55 \%$ decrease in TG levels and a $30.09 \%$ increase in RBC count compared to control group, similar to the results of Son et al [23] (Table 1). The studies also confirmed an increased effect of active saponins using the blood analysis [24].

MSCs, which are multi-potent progenitors with multi-lineage differentiation ability, are widely used as stem cells for tissue engineering. [25]. Reducing stem cell differentiation time would lead to a rapid increase in cell number. Figure 1 shows the results of doubling time of MSCs. These results indicated that MSCs treated with $10 \mathrm{ng} / \mathrm{mL}$ of active saponins showed the lowest PDT. Wang et al [26] reported that MSCs could improve tumor drug resistance when compound $\mathrm{K}$ was administered to tumor-bearing mice. This effect may have been mediated by MSCs.

Figure 1 also shows PDT results for A549 cells. A549 cells treated with $10 \mathrm{ng} / \mathrm{mL}$ of active saponins showed the highest PDT, highlighting the cancer growth retardation potential of the active saponins. This result confirmed those of Shin et al [27], in which compound $\mathrm{K}$ showed cytotoxic and apoptotic activities in A549 cells. 
Suppression of $\beta$-galactosidase activity in cultured cells suggests an extension of cellular lifespan [28]. Many researchers have studied substances that extend cellular lifespan and have made efforts to identify safe substances that inhibit $\beta$-galactosidase [29-31]. These results showed suppression of $\beta$-galactosidase activity in response to treatment with active saponins. Treatment with $10 \mathrm{ng} / \mathrm{mL}$ of active saponins led to an average reduction (Den1, Den2, and Den3) of $\beta$-galactosidase $(20.42 \pm 0.49 \%)$ in HTS cells isolated from the three volunteers (Figure 2). As shown in Figure 3 , a large decrease in $\beta$ galactosidase activity was also seen following active saponin treatment compared with that in controls. Although $\beta$-galactosidase staining is not a representative method for senescenceassociated changes in some human cells, it may serve as a biomarker of aging [32].

\section{CONCLUSION}

These results have industrial applicability as they demonstrate a pharmaceutical composition which contains ginseng-derived active saponins useful for increasing RBC count, reducing triglyceride and $\beta$-galactosidase levels, promoting MSC cell differentiation, and suppressing A549 cell differentiation prepared by removing sugars using heat and enzyme treatments.

\section{DECLARATIONS}

\section{Acknowledgement}

This research was financially supported by the Ministry of SMEs and Startups (MSS), Korea, under the harmful organic solvents to be useful to increase D, R0006207)" supervised by the Korea Institute for Advancement of Technology (KIAT).

\section{Conflict of interest}

No conflict of interest is associated with this work.

\section{Contribution of authors}

We declare that this work was done by the authors named in this article and all liabilities pertaining to claims relating to the content of this article will be borne by the authors. Sin Ja Bae performed experiments. Gyu Jin Rho reviewed this manuscript and designed this study. Kang Min Kim and Jae Seon Kang drafted this manuscript and supervised the other authors.

\section{REFERENCES}

1. Park HJ, Kim DH, Park SJ, Kim JM, Ryu JH. Ginseng in traditional herbal prescriptions. J Ginseng Res 2012; 36 : 225-241.

2. Kevers $C$, Jacques $P$, Gaspar $T$, Thonart $P$, Dommes $J$. Comparative titration of ginsenosides by different techniques in commercial ginseng products and callus cultures. J Chromatogr Sci 2004; 42: 554-558.

3. Hwang JB, Ha JH, Hawer WD, Nahmgung B, Lee BY. Ginsenoside contents of Korean white ginseng and taegeuk ginseng with various sizes and cultivation years. Korean J Food Sci Technol 2005; 37: 508-512.

4. Lee JY, Kwon OJ, Noh JS, Roh SS. Protective effects of red ginseng according to steaming time on $\mathrm{HCL} /$ ethanolinduced acute gastritis. J Appl Biol Chem 2016; 59: 365372.

5. Ok S, Kang JS, Kim KM. Simultaneous analysis method for polar and non-polar ginsenosides in cultivated wild ginseng by reversed-phase HPLC-CAD. J Life Sci 2016; 26: 247-252.

6. Kim JH. Pharmacological and medical applications of Panax ginseng and ginsenosides: a review for use in cardiovascular diseases. J Ginseng Res 2018; 42: 264269.

7. Park EK, Shin YW, Lee HU, Kim SS, Lee YC, Lee BY, Kim DH. Inhibitory effect of ginsenoside $R b 1$ and compound $\mathrm{K}$ on $\mathrm{NO}$ and prostaglandin $\mathrm{E2}$ biosyntheses of RAW264.7 cells induced by lipopolysaccharide. Biol Pharm Bull 2005; 28: 652-656.

8. Lee $H U$, Bae EA, Han MJ, Kim NJ, Kim DH. Hepatoprotective effect of ginsenoside $R b 1$ and compound $K$ on tert-butyl hydroperoxide-induced liver injury. Liver Int 2005; 25: 1069-1073.

9. Rausch WD, Liu S, Gille G, Radad K. Neuroprotective effects of ginsenosides. Acta Neurobiol Exp 2006; 66: 369-375.

10. Shoji S. Chemistry and cancer preventing activities of ginseng saponins and some related triterpenoid compounds J Korean Med Sci 2001; 16: S28-37.

11. Lee KJ, Lee SY, Ji GE. Diabetes-ameliorating effects of fermented red ginseng and causal effects on hormonal interactions: testing the hypothesis by multiple group path analysis. J Med Food 2013; 16: 383-395.

12. Akao $T$, Kida $H$, Kanaoka $M$, Hattori $M$, Kobashi $K$. Intestinal bacterial hydrolysis is required for the appearance of compound $K$ in rat plasma after oral administration of ginsenoside Rb1 from Panax ginseng. J Pharm Pharmacol 1998; 50: 1155-1160.

13. Ullah I, Subbarao RB, Rho GJ. Human mesenchymal stem cells-current trends and future prospective. Biosci Rep 2015; 35: e00191.

14. Bharti D, Shivakumar SB, Park JK, Ullah I, Subbarao RB, Park JS, Lee SL, Park BW, Rho GJ. Comparative analysis of human Wharton's jelly mesenchymal stem cells derived from different parts of the same umbilical cord. Cell Tissue Res 2018; 372: 51-65. 
15. Debacq-Chainiaux F, Erusalimsky JD, Campisi J, Toussaint $O$. Protocols to detect senescence-associated beta-galactosidase (SA-betagal) activity, a biomarker of senescent cells in culture and in vivo. Nat Protoc 2009; 4: $1798-1806$.

16. Cui CH, Liu QM, Kim JK, Sung BH, Kim SG, Kim SC, Im WT. Identification and characterization of a Mucilaginibacter sp. strain QM49 $\beta$-glucosidase and its use in the production of the pharmaceutically active minor ginsenosides (S)-Rh1 and (S)-Rg2. Appl Environ Microbiol 2013; 79: 5788-5798.

17. Kumar S, Pandey AK. Chemistry and biological activities of flavonoids: An overview. Scientific World Journal 2013; 2013; 162750.

18. Choi HS, Kim S, Park YH, Jung EY. Enzymatic transformation of ginsenosides in Korean Red Ginseng (Panax Ginseng Meyer) extract prepared by Spezyme and Optidex. J Ginseng Res 2014; 38: 264-269.

19. Hasegawa $\mathrm{H}$. Proof of the mysterious efficacy of ginseng: basic and clinical trials: metabolic activation of ginsenoside: deglycosylation by intestinal bacteria and esterification with fatty acid. J Pharmacol Sci 2004; 95: 153-157.

20. Bae EA, Han MJ, Choo MK, Park SY, Kim DH. Metabolism of 20(S)- and 20(R)-ginsenoside rg3 by human intestinal bacteria and its relation to in vitro biological activities. Biol Pharm Bull 2002; 25: 58-63.

21. Niccoli $T$, Partridge L. Ageing as a risk factor for disease. Curr Biol 2012; 22: R741-752.

22. Shytikov D, Balva O, Debonneuil E, Glukhovskiy $P$, Pishel I. Aged mice repeatedly injected with plasma from young mice: A survival study. BioResearch 2014; 3: $226-232$

23. Son II, Park YH, Lee SI, Yang HD, Moon HI. Neuroprotective activity of triterpenoid saponins from Platycode radix against glutamate-induced toxicity in primary cultured rat cortical cells. Molecules 2007; 12 : 1147-1152.

24. Kim SK, Kim CJ, Kim H, Lim YT, Yoon SJ. The Effects of mixtures with ginseng radix rubra and paeonia radix on endurance exercise performance. J Ginseng Res 2007; 31: 93-101.

25. Nancarrow-Lei $R$, Mafi $P$, Mafi $R$, Khan W. A systemic review of adult mesenchymal stem cell sources and their multilineage differentiation potential relevant to musculoskeletal tissue repair and regeneration. Curr Stem Cell Res Ther 2017; 12: 601-610.

26. Wang $W$, Zhong $W$, Yuan J, Yan $C$, Hu S, Tong $Y$, Mao $Y$, Hu T, Zhang B, Song $G$. Involvement of Wnt/ $\beta$ catenin signaling in the mesenchymal stem cells promote metastatic growth and chemoresistance of cholangiocarcinoma. 2015; 6: 42276-42289.

27. Shin DH, Leem DG, Shin JS, Kim JI, Kim KT, Choi SY, Lee $M H$, Choi JH, Lee KT. Compound $K$ induced apoptosis via endoplasmic reticulum $\mathrm{Ca} 2+$ release through ryanodine receptor in human lung cancer cells. $J$ Ginseng Res 2018; 42: 165-174.

28. Jeong DU, Byeon JS, Lee J, Park MJ, Gu NY, Cho IS, Cha SH. Effects of cryopreservation on equine adipose tissue-derived mesenchymal stem cell plasticity. J Prev Vet Med 2018; 42: 1-9.

29. Choi SI, Lee JS, Lee SR, Lee HJ, Kim BJ, Yeo JH, Jung $T D$, Cho BY, Choi SH, Lee JH, Kim JY, Lee $\mathrm{OH}$. Antioxidant and anti-aging effects of extracts from leaves of Castanea crenata Siebold \& Zucc. in human dermal fibroblast. J Food Hyg Saf 2017; 32: 243-248.

30. Oh JY, Kim JH, Lee GS, Zhang YH, Pyo HB. Antioxidative and Anti-aging Effects of Extract from Talinum paniculatum. J. Soc. Cosmet. Scientists Korea 2013; 39: 313-322.

31. Park SR, Bak KJ, Ok CY, Park HJ, Jang HO, Bae MK, Bae SK. Melatonin Rescues Human Dental Pulp Cells from Premature Senescence Induced by $\mathrm{H}_{2} \mathrm{O}_{2}$. Int $\mathrm{J}$ Oral Biol 2017; 42: 91-97.

32. Dimri GP, Lee X, Basile G, Acosta M, Scott G, Roskelley C, Medrano EE, Linskens $M$, Rubelj I, Pereira-Smith $O$, Peacocke M, Campisi J. A biomarker that identifies senescent human cells in culture and in aging skin in vivo. Pro Natl Acad Sci 1995; 92: 9363-9367. 